\title{
The Way of Yield Increasing and Cost Reducing in Agriculture: Smart Irrigation and Fertigation
}

\author{
Muhammet Karaşahin ${ }^{1}$, Özgür Dündar ${ }^{2 *}$, Ahmet Samancı ${ }^{3}$ \\ ${ }^{1}$ Department of Organic Farming Management, Çumra School of Applied Science, Selçuk University, 42500 Çumra/Konya, Turkey \\ ${ }^{2}$ Department of Satellite and Space Engineering, Faculty of Aeronautical and Space Science, Necmettin Erbakan University, 42075 Konya, Turkey \\ ${ }^{3}$ Department of Energy Systems Engineering, Faculty of Engineering, Necmettin Erbakan University, 42075 Konya, Turkey
}

\section{A R T I C L E I N F O}

\section{Review Articles}

Received 25 April 2018

Accepted 01 September 2018

Keywords:

Dynamic fertigation

Irrigation use efficiency methods

Fertigation use efficiency methods

Yield

Productivity

*Corresponding Author:

E-mail: ozdundar@konya.edu.tr

\section{A B S T R A C T}

The plants can only use the around $50 \%$ of the applied nitrogenous fertilizer. It has been observed that the dynamic fertigation applications help to improve the fertilizer effectiveness. In the dynamic fertigation approach, water and plant nutritional elements are calculated and determined according to the plant dry matter generation rate and root volume. Smart agriculture is an knowledge based decision making approach established upon quantification and observations of the changes in each level of production. With this system, saving can be provided by only supplying the plant's daily need of water and fertilizer and preventing the excess irrigation and fertilizing, so yield increase can be achieved by keeping away the plants from the stress conditions. Agricultural production can be increased five times by irrigation but shortening in water sources and decrease in quality reasoned by fast growing are restricted of irrigation which is the main user of freshwater sources. Increasing the water and fertilizer effectiveness with the smart irrigation techniques which can save water and fertilization management applications are the essential strategies to be able to reach the yield increase in order to supply the growing food needs of developing population and help to minimize the environmental damage. In the study, the researches and applications related to smart irrigation and fertilization were tried to be included in a wide scope and tried to keep a light to obtain higher yield with less water and fertilizer use in agriculture.

Türk Tarım - Gıda Bilim ve Teknoloji Dergisi, 6(10): 1370-1380, 2018

\section{Tarımda Verim Artıșı ve Tasarrufun Yolu: Akılı Sulama ve Gübreleme}

\section{A K A L E B İ L G İ S İ}

\section{Derleme Makale}

Geliş 25 Nisan 2018

Kabul 01 Eylül 2018

Anahtar Kelimeler:

Dinamik fertigasyon

Su kullanım etkinliği

Gübre kullanım etkinliği

Verim

Verimlilik

*Sorumlu Yazar:

E-mail: ozdundar@konya.edu.tr

\section{Ö Z}

Toplam uygulanan azotlu gübrelerin yaklaşık olarak sadece \%50'si bitkiler tarafindan alınabilmektedir. Dinamik fertigasyon uygulamalarının gübre kullanım etkinliğinde önemli artış sağladığı görülmüştür. Dinamik fertigasyon yaklaşımında su ve bitki besin elementleri bitki kuru madde üretimi ve kök hacmine göre günlük hesap edilerek belirlenmektedir. Akıllı tarım üretimin her aşamasında değişimleri ölçme ve gözlemleme üzerine kurulu bilgi temelli karar verme yaklaşımıdır. Bu sistemde bitkinin günlük su ve gübre ihtiyaçları karşılandığı için aşırı sulama ve gübrelemenin önüne geçilerek girdi kullanımında tasarruf sağlanmakta, bitki stres şartlarına maruz kalmadığı için verim artışları elde edilmektedir. Sulama ile bitkisel üretimi 5 kat artırmak mümkündür, ancak su kaynaklarının azalması ve hızlı büyüme nedeniyle kalitesinin bozulması tatlı su kaynaklarının en büyük kullanıcısı olan tarımda su kullanımını kısıtlama yoluna gidilmesini zorunlu kılmaktadır. Su tasarrufu sağlayan sulama teknikleri ile akıllı sulama ve gübreleme yönetim uygulamalarıyla su ve gübre kullanım etkinliğinin artırılması böylece çevre üzerine olan olumsuz etkilerin en aza indirilmesinde ve artan nüfusun gida ihtiyacının karşılanmasında kaçınılmaz olan verim artışlarını yakalamada vazgeçilmez stratejilerdendir. Çalışmada akıllı sulama ve gübreleme ile ilgili yapılmış araştırmalar ve uygulamalara geniş kapsamda yer verilmeye çalışılarak tarımda daha az su ve gübre kullanımı ile daha yüksek verim elde etmeye yönelik ışık tutulmaya çalışılmıştır. 


\section{Introduction}

It is estimated that the world population will reach 9 billion by 2050. Supplying the food needs of the growing population will be possible by using the agricultural land more efficiently, applying of advanced agricultural technologies, genetic studies, irrigation and balanced fertilization widely (Blanco, 2011). In 2016 it is estimated that there will be 193.9 million tons of chemical fertilizers worldwide and its economic value will be $\$ 63.5$ billion. Nitrogenous fertilizers account for $60 \%$ of this amount (FAO, 2016).

The world average is around $50 \%$ with changes in nitrogen uptake efficiency, production management practices and product types. The economic value of the unaccountable nitrogen is equivalent to 19.5 billion dollars per year (Brentrup and Palliere, 2011). This amount that can not be used by the plant, kills biological nitrogen fixation microorganisms and is transported together with precipitation and irrigation water to generate eutrophication in water resources, accumulation of nitrate in underground drinking water, acid rain through denitrification, with the greenhouse effect cause to global warming and ozone layer thinning which are constitutes pollution elements (Gupta and Khosla, 2014). Nitrate entering the human body through drinking water with a high nitrate content and foods, changes into the nitrite and then forms nitrosamines by reacting with secondary amines. These compounds are also known to be toxic, teratogenic, mutagenic and carcinogenic (Ekici et al., 2008).

The way to reduce the amount of nitrogen fertilizer required to make agricultural production enough to feed the growing world population and the negative effects that these fertilizers have on the environment and human health is due to the increase in nitrogen uptake efficiency (Karaşahin, 2014a). Irrigation program together with fertilizer dosage is an important influence on the leaching of the nitrogen. With irrigation management, nitrogen uptake from the effective root zone can be greatly increased. Overirrigation promotes the transport of plant nutrients in the soil which has lower water holding capacity, before plants are uptake (Zotarelli et al., 2008). Precision irrigation program should be applied to minimize nitrogen leaching in soil with low water holding capacity.

Intelligent agriculture is involving the factors such as low cost, variable input use, maximum income targeting and environmental protection principles in the framework of integrating developing technologies with agricultural production. In this approach, agricultural inputs such as labour, water, fertilizers, chemicals, seeds, machinery and energy are used less and this contributes to sustainable agricultural production with the result of increase in profitability (Zarco-Tejada, 2014). This study summarized the literature on smart irrigation and fertilization and attempted to shed light on achieving higher yields with less water and fertilizer uses in agriculture.

\section{Smart Irrigation}

It is possible to increase crop production by 5 times with irrigation, but due to decrease of water resources and degradation of quality caused by rapid growth, necessitates restriction of water usage in agriculture which is the biggest user of fresh water resources. Watersaving irrigation techniques and selection of droughttolerant plant varieties are indispensable strategies for protecting soil and water resources and meeting the food needs of the growing population. The use of irrigation methods and systems which will increase productivity and quality are gaining increasing importance every day, which will not cause drainage and salinity problems in the soil with more economical applications by using less irrigation water (Aras, 2006). While reducing the amount of water used in agriculture, the way to increase the efficiency is to use more effective irrigation methods by making more sensitive irrigation programs.

In smart irrigation and fertilization systems developed for water, fertilizer and energy saving and productivity increase, there are fertilizer tanks, dosing pumps, control units and valves, soil moisture meters as well as sensors for soil and fertilizer solution $\mathrm{pH}$ and $\mathrm{EC}$ measurement. In this system, since the plant meets daily water and fertilizer needs, excessive irrigation and fertilizing are avoided and the use of inputs is saved. As plant are not exposed to stress conditions, yield increases are obtained (Bin Mohd Juaser, 2014).

\section{Methods Used in Irrigation Program}

Determining the onset of irrigation can be seen primarily as the application of a variety of assessment techniques to characterize and identify field-scale moisture dynamics and plant water use both temporally and locally. These assessment methods can be classified under three main headings as soil, weather conditions and vegetative perception (Steele et al., 1994).

The latest developments in remote sensing have made it possible to monitor both soil and vegetation conditions. Remote sensing includes non-contact technologies that can detect radiation emitted or emitted from agricultural areas. These include satellites, air platforms and tractors usage (Mulla, 2013).

Decision support systems for irrigation management and schedules provide a framework that integrates various tools and techniques for applied field-specific irrigation decisions (Smith et al., 2009).

Soil-based determination: In irrigation programming and management, the knowledge of soil moisture flows including the consumption and filling of soil water is used. The irrigation program is to determine when and how much irrigation will be done. Starting of irrigation is the time when $10-50 \%$ of the useful water between the initial field capacity and the wilting point of is consumed. The amount of irrigation is to determine the amount of water to bring the effective root zone to field capacity by various methods (French et al., 2014; Karasahin, 2014b). In precision irrigation, a method based on dielectrics is commonly used to follow the temporal dynamics of soilmoisture (Table 1a and 1b). Dielectric soil moisture sensors work by using of the dielectric properties of soil and its components (Phillips et al., 2014). The relative dielectric permeability of a material is used to determine the effect of its electromagnetic field and its molecular structure. The relative dielectric permeability that appears in the soil is a function of its components, mainly water, air and solid particles. 
Table 1a Soil moisture measurement techniques*

\begin{tabular}{|c|c|c|c|}
\hline MT & Advantages & Disadvantages & Sample \\
\hline Hand & Easy and simple implementation & High error rate & \\
\hline Gravimetric & High accuracy & $\begin{array}{l}\text { High labour and time requirements for } \\
\text { sampling and laboratory work }\end{array}$ & \\
\hline \multicolumn{4}{|c|}{ Densiometric } \\
\hline Tensiometer & $\begin{array}{l}\text { Accuracy, Instantaneous humidity } \\
\text { tracking }\end{array}$ & $\begin{array}{l}\text { Labour required for reading, Need for } \\
\text { maintenance, Reading error after } 0.7 \text { bar }\end{array}$ & \\
\hline Gypsum blocks & $\begin{array}{l}\text { Minimal maintenance needs, Simple } \\
\text { and cheap, It is reliable up to } 6 \mathrm{dS} / \mathrm{m} \\
\text { against salinity }\end{array}$ & $\begin{array}{l}\text { Low sensitivity, Not suitable for } \\
\text { measurement of saturation, Not suitable for } \\
\text { sandy soils }\end{array}$ & \\
\hline $\begin{array}{l}\text { Granular } \\
\text { Matrix }\end{array}$ & $\begin{array}{l}\text { Minimal maintenance needs, Simple } \\
\text { and cheap, it is reliable up to } 6 \mathrm{dS} / \mathrm{m} \\
\text { against salinity }\end{array}$ & $\begin{array}{l}\text { Low sensitivity, Not suitable for } \\
\text { measurement of saturation, Not suitable for } \\
\text { sandy soils }\end{array}$ & \\
\hline $\begin{array}{l}\text { Heat } \\
\text { distribution }\end{array}$ & $\begin{array}{l}\text { Large measurement range, Minimal } \\
\text { maintenance needs, Continuous } \\
\text { reading, Not affected by salinity }\end{array}$ & $\begin{array}{l}\text { Reading in heat exchanges requires } \\
\text { experience, Slow reaction time, Not } \\
\text { suitable for sandy soils, High power } \\
\text { consumption }\end{array}$ & \\
\hline Psychrometer & $\begin{array}{l}\text { High sensitivity, Suitable for other } \\
\text { soil moisture conditions except for } \\
\text { extreme drought }\end{array}$ & $\begin{array}{l}\text { Not recommended for surface soils, Slow } \\
\text { reaction time, Low detection volume }\end{array}$ & \\
\hline \multicolumn{4}{|c|}{ Volumetric } \\
\hline TDR & $\begin{array}{l} \pm 1 \% \text { Sensitivity, Conformity to } \\
\text { various soil depths, Minimal soil } \\
\text { degradation, Simultaneous } \\
\text { measurement }\end{array}$ & $\begin{array}{l}\text { Relatively expensive device, Limited } \\
\text { sensitivity in highly saline and very clayey } \\
\text { soils, Need calibration for high humidity } \\
\text { content }\end{array}$ & \\
\hline FDR & $\begin{array}{l}\text { Soil-specific } \pm 1 \% \text { accuracy after } \\
\text { calibration, can be used in high salty } \\
\text { soils where TDR fails, Measuring at } \\
\text { different depths in the same position, } \\
\text { Cheaper than TDR }\end{array}$ & $\begin{array}{l}\text { Detection sensitivity is lower, No gap } \\
\text { should be between soil and sensor for } \\
\text { reliable measurements, Soil-specific } \\
\text { calibration is required, Higher influence } \\
\text { from temperature change than TDR }\end{array}$ & \\
\hline ADR & $\begin{array}{l}\text { Sensitivity } \pm 1 \% \text { with calibration, } \pm \\
5 \% \text { without calibration, measuring in } \\
\text { saline conditions up to } 20 \mathrm{dS} / \mathrm{m} \text {, } \\
\text { Minimal soil degradation, Lower } \\
\text { costs, Not affected by heat }\end{array}$ & $\begin{array}{l}\text { Soil-specific calibration for reliable } \\
\text { measurement, Small sensing volume, } \\
\text { Measurements affected by air gap, gravel } \\
\text { and water contact to probe tip }\end{array}$ & \\
\hline
\end{tabular}


Table 1b Soil moisture measurement techniques*

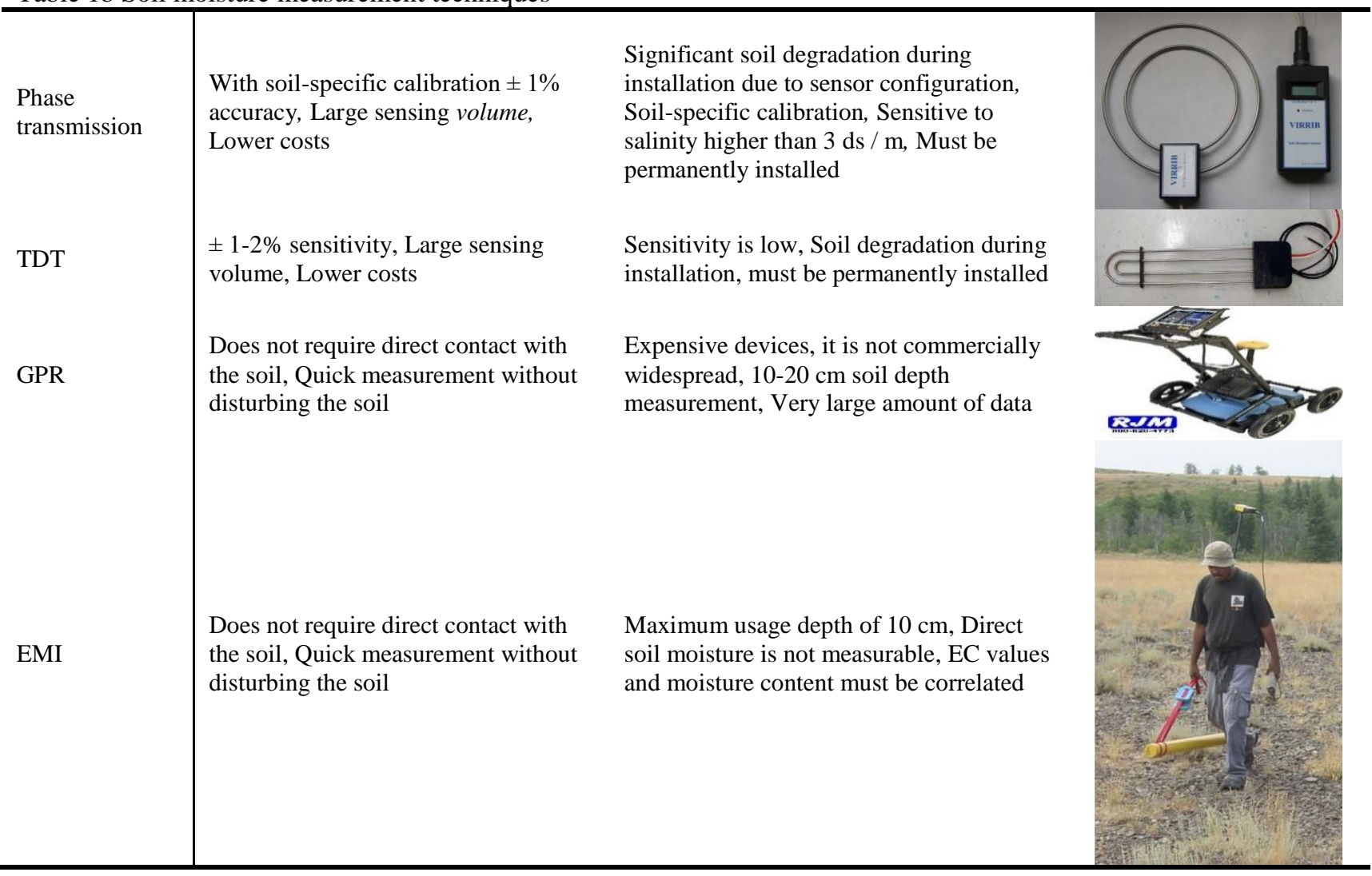

MT: Measurement Techniques; *Munoz-Carpena et al. (2004)

Electrical permeability in other components except water has an insignificant effect because they have small values in the range of 1-7. The effect of water having a relative dielectric permeability value of about 80 is large. For this reason, it is possible to relate volumetric soil moisture content to empirical equations in a frequency range of $50 \mathrm{MHz}$ to $17 \mathrm{GHz}$ (Adeyemi et al., 2017). A range of electromagnetic sensors, such as time domain reflectometry (TDR), time domain transmission (TST), and capacitance sensors, provide a non-destructive in-situ measurement of soil moisture content (Table 1a and 1b). The accuracy of data from soil moisture sensors is important in precision irrigation. High measurement of the soil moisture delays the start time of the irrigation in the program, which adversely affects the yield and quality of the crops. On the other hand, low measurement of soil moisture results in excessive irrigation, which results in negative environmental impacts with waste water/energy waste.

Factors such as electrical conductivity (salinity), soil texture, bulk density and temperature affect the performance of dielectric soil moisture sensors. These properties differ in location and soil profile depth, and it is necessary to account for these properties when calibrating dielectric soil moisture sensors (Geesing et al., 2004). For high-precision accuracy, a special calibration must be performed on the field. In this calibration, gravimetric moisture is read from the soil samples to represent the plantation area and calibrated by comparing sensor readings at the same humidity (Rowlandson et al., 2013). In addition, the placement of inlet tubes of capacitance-type sensor probes into the soil without air space is important for accurate measurements.
Recent developments in rapid mapping and positioning technologies offer the opportunity to characterize soil moisture holding in the scheduling of precision irrigation programming. The electromagnetic induction (EMI) technique is used with accurate positioning systems to determine the soil moisture variability at resolutions lower than $10 \mathrm{~m}$ (Table 1). The EMI sensor maps the apparent EC of the soil, affected by soil texture and moisture in salt-free soil. These EC maps are largely related to the water holding capacity of the soil. From this EC map, dynamic water maps of the soil are formed and used in the irrigation program (Hedley and Yule, 2009). The associated groundwater radar (GPR) is used to track the soil moisture in the field scale applicable. It can be fitted on a moving grate or irrigation system to form the moisture map of the ground (Table 1a and $1 \mathrm{~b}$ ). However, the ground radar, which is affected by high clay content, is not suitable for automation and needs further development to increase its applicability in precision irrigation (Bogena et al., 2007).

Determination based on weather conditions: Determination based on weather conditions involves the use of climate variables to determine evapotranspiration (ET), a marker of daily water consumption of plants. Evaporation accounts for the evaporation of water from the soil to the air through the soil surface, and rain or irrigation water is holded by the plant canopy. In the calculation of transpiration, the amount of water lost by the leaves and stomata as vapour which is taken into account for metabolic cooling to prevent overheating of the leaves for continuation of photosynthesis (Adeyemi et al., 2017). Evapotranspiration is usually seen as a combination of water evaporating from the soil surface, 
canopy surface evaporation and plant transpiration. Evaporation is largely dependent on solar radiation, atmospheric vapor pressure deficit, and wind velocity. Furthermore, the soil is influenced by plant characteristics such as water content, plant root density and also properties which are affecting the amount of water taken from the soil like species, variety, stage of development (Pereira et al., 2014). In direct measurement methods, a water budget equation based on conservation of mass is used. In determining the plant water consumption (ETc), Penman-Monteith equality which is based on grass plant, is used as a reference.

Remote sensing is useful in overcoming the difficulties experienced in ET calculation based on plant coefficient. The normalized difference vegetation index (NDVI) calculated by the reflection measurements of plant canopy in red and near infrared (NIR) wavelengths has been found to be a useful method for calculating the correct plant coefficients in wide product range (Hunsaker et al., 2003; Singh et al., 2013).

Determination based on plants: The temporal dynamics of plant water use can be followed by some plant-based methods. These methods include approaches which need direct contact with the plants or close contact (Adeyemi et al., 2017). Plant-based detection systems measure both plant water content and potential as well as physiological responses to water deficiencies (Table 2). Plant canopy temperature is a widely accepted variant to determine the status of plant water. Stomata control the cooling that occurs due to evaporation on the leaves, based on the state of soil water and on the current environmental conditions. Stomata are closed due to increased water deficiencies and reductions in plant transpiration. After all, the canopy temperature rises. The information obtained from the measurement of the plant canopy temperature by the infrared thermometer is used to calculate indices such as crop water stress index (CWSI) after normalization. These indexes are used to determine the physiological responses of the plant to water conditions and water deficiencies (Blonquist et al.,
2009). CWSI is an index of the difference between the air temperature and the plant canopy temperature obtained with infrared thermometer readings and this difference is a result of atmospherically vapour deficiency. This difference in temperature is then associated with an upper and lower temperature level to determine the water stress index. At the upper reference temperature determined in the same environmental conditions, it is assumed that the plant does not transpire and that it totally transpires at the lower reference temperature (Shaughnessy et al., 2014). CWSI is a value which has not any intermediate value between 0 and 1.0 represents a well irrigated plant and 1 defines the plant with serious level of water deficiency (Erdem et al., 2010). The main advantage of thermal sensing for sensitive irrigation applications is that the system has a non-contact and real-time measurement. Infrared thermometer and thermography provide an opportunity to map the variability of the plant water condition that can be used in variable rate irrigation management applications. The biggest problem encountered in implementing the thermal sensing approach is to determine the reference temperatures. Changes in wind speed and net radiation in the climate where the weather is mostly high in moisture make significant mistakes in estimating the lower level reference temperature (Adeyemi et al., 2017). Another problem that is commonly encountered in applications where canopy temperature determinations are used with infrared measurements when the water condition is determined is the measurement of the canopy temperature, including soil temperature and other background temperatures. This usually leads to faults in determining the canopy temperature, because the soil and background temperatures are often quite different from the canopy temperature (Meron et al., 2010). In order to solve this problem, infrared sensors which can measure in narrow angles are placed to read only from the leaves, but this alternative does not reflect the real canopy temperature because the reading is done only from the leaves.

Table 2 Some of the methods of determining plant-based water content and their advantages and disadvantages*

\begin{tabular}{|c|c|c|}
\hline Methods & Advantages & Disadvantages \\
\hline \multicolumn{3}{|c|}{ Determination of plant water potential } \\
\hline $\begin{array}{l}\text { Leaf turgor } \\
\text { pressure sensors }\end{array}$ & $\begin{array}{l}\text { Real time measurements can be made, } \\
\text { Leaf water dynamics can be characterized }\end{array}$ & Point based, must be removed to canopy level \\
\hline \multicolumn{3}{|c|}{ Determination of plant water content } \\
\hline $\begin{array}{l}\text { Leaf thickness } \\
\text { sensors }\end{array}$ & $\begin{array}{l}\text { It is relatively inexpensive and suitable for } \\
\text { automation }\end{array}$ & $\begin{array}{l}\text { Leaf thickness is not sensitive to plant water status } \\
\text { changes, Sensors have low resolution and high error } \\
\text { rates }\end{array}$ \\
\hline $\begin{array}{l}\text { Stem diameter } \\
\text { changes }\end{array}$ & $\begin{array}{l}\text { Sensitive to water deficiencies and suitable } \\
\text { for automation }\end{array}$ & Limited by daily delays, Has low resolution \\
\hline \multicolumn{3}{|c|}{ Determination of physiological responses of plant to water deficiency } \\
\hline Xylem gaps & $\begin{array}{l}\text { Sensitive in determining the start of water } \\
\text { stress, Partially cheaper tools }\end{array}$ & $\begin{array}{l}\text { Only useful in drought conditions, Insufficient to } \\
\text { characterize gaps and water relations, Has low } \\
\text { resolution }\end{array}$ \\
\hline Plant juice flow & $\begin{array}{l}\text { Has high accuracy in determining plant } \\
\text { transcription }\end{array}$ & $\begin{array}{l}\text { Point-based technique that requires repetition to } \\
\text { increase resolution, It is difficult to determine } \\
\text { irrigation thresholds, Its use is very time consuming } \\
\text { and requires expertise }\end{array}$ \\
\hline Thermal sensing & $\begin{array}{l}\text { Easy to use, it has high temporal and } \\
\text { spatial resolution }\end{array}$ & $\begin{array}{l}\text { It is generally based on observation, Application in } \\
\text { wet climates is difficult }\end{array}$ \\
\hline
\end{tabular}


The frequent use of infrared sensors may be a solution, but its practical implementation is limited due to the high cost. The recent progress in the field of thermal imaging and the production of low cost thermal cameras offers the possibility of solving problems related to the inclusion of soil and background temperatures at the measured canopy temperature. Thermal imaging allows the average temperature of a given area to be obtained, as well as the background temperature to leave interest. In addition, thermal imaging equipment can be fitted onto unmanned aerial vehicles provides quick mapping of area-sized plant water status. Plant-based detection methods, including thermal sensing, provide information only on the beginning of irrigation, and provide no information about the amount of irrigation water required. For this reason, they are used in conjunction with soilbased detection (Smith et al., 2009). Some of the methods for determining plant-based water content and their advantages and disadvantages are given in Table 2 .

Decision support systems: Decision support systems for irrigation management and schedules provide a framework that integrates various tools and techniques for applied field-specific irrigation decisions (Smith et al., 2009). Some decision support systems plan and implement irrigation with predefined intervals and quantities. They do not take the climatic data into account with the sensor readings which determine the state of plant and soil water. This "open circuit" decision is the support strategy. This system is designed based largely on estimated and historical data. It has been suggested that such a management system is an inefficient approach, causing excessive waste of irrigation and fertilizers and other inputs (Lozoya et al., 2014). In the "closed circuit" irrigation strategies, irrigation program is made with the feedback of the plant simulation models when the amount of soil moisture is detected with soil or plant sensors reaching a certain threshold. In this irrigation strategy, water use efficiency, product yield and quality have been observed to increase (Vellidis et al., 2008; Liu et al., 2012). The plant needs in land-scaled production vary both temporally and spatially depending on biotic and abiotic factors. In the closed circuit irrigation strategies, unexpected changes in plant development due to disease and pest infestation and natural phenomena are not taken into consideration. Decision support system should have the ability to change irrigation decisions according to plant physiology, uncertainties of climatic inputs, soil, irrigation systems and water resource constraints, economic factors and sensor feedback quality. The adaptive decision support system should have the ability to continuously reset the irrigation program to maintain the desired performance of the irrigation system. In adaptive irrigation decision support strategies, an irrigation program based on both calibratable simulation model based on direct sensor measurements can be prepared (McCarthy et al., 2010).

Plant simulation models are based on the physical principles of plant phenology, soil physics, and hydrology, which can be applied to the simulation of reactions that plants have given to the irrigation and production management system. These simulation models provide the opportunity to take advantage of a variety of precise irrigation strategies as it removes the need for time-consuming field measurements (Jones et al., 2014). In the meantime, they can be used to predict the efficiency effect of the irrigation strategy. However, these systems do not provide real-time decision support, but can only be implemented using historical data.

Hybrid expert systems also referred to as model-based expert systems, combine algorithmic techniques and knowledge-based elements to solve application-related problems. The advantage of the irrigation is that they can decide the optimum irrigation by combining expert knowledge and feedback information from in-field sensors (Rani et al., 2011). A mistake in this process greatly affects system reliability and performance.

Calibration control decision support strategies perform system identification using sensor feedback without defining a mathematical model (McCarthy et al., 2010). The time-varying nature of the soil-plant-atmospheric system can also be seen as a problem not defined well. The results of the calibration control model are solely based on sensor measurements; therefore, they can be greatly influenced by sensor errors. This method is considered as a "brute force" approach rather than a scientifically based approach to planning irrigation (Adeyemi et al., 2017).

The predictive control model (PCM) is an industrial control approach used for decision support of large scale multivariable problems with multiple constraints. The predictive control model is a plant model and optimization algorithm that calculates plant inputs to achieve a specified yield potential. When the soil moisture balance model is applied as irrigation is being carried out, the amount of irrigation of the plant entrance will be the amount of soil moisture released, and the plant evapotranspiration and rainfall values will both be regarded as uncontrollable elements (Adeyemi et al., 2017).

\section{Smart Fertilization}

To minimize nitrogen losses and increase nitrogen uptake efficiency; sufficient effective agricultural management practices such as soil analysis and determination of fertilizer dosage according to plant requirement, increase of soil organic matter, irrigation program prepared by taking into account the plant root zone and field capacity with pressure irrigation methods, application of fertilizer with irrigation water considering the plant development periods, irrigation program considering pressure of irrigation methods and plant root region and field capacity, application of fertilizer with irrigation water considering the plant development periods, fertilizer application to the place where the plant can use by dividing not in one go where the rainfall is sufficient, preference of slow release fertilizers, control of weed, preference of high variety of nitrogen intake activity, alternation of leguminous and deep rooted plants, proper tillage and sowing time, optimum plant density are suggested (Karasahin, 2014a). With advanced irrigation and fertilization management practices, it is inevitable to increase the efficiency of fertilizer intake and thus minimize the adverse effects on the environment. Wellmanaged irrigation and fertilization programs increase nitrogen uptake and minimize environmental impacts in 
commercial production. For this reason, it has been reported that irrigation and fertilization programs should be improved in order to prevent both nitrogen leach and economically loss of nitrogenous fertilizer.

Dynamic fertigation practices have shown a significant increase in nitrogen utilization efficiency. Fertigation is the application of plant nutrients to the soil or plant root zone together with irrigation water through irrigation systems with a simple description (Çetin, 2015).

Fertigation is an agricultural process in which fertilizer is dissolved in irrigation water and applied to irrigation system and plant root zone. This combination provides a timely and spatially sensitive mineral fertilizer application technique (Figure 1).

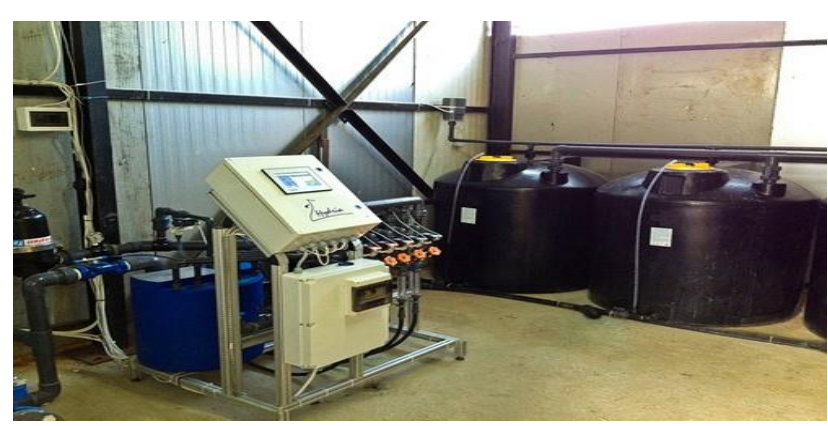

Figure 1 Fertigation system

While the first scientific fertigation application was carried out in the United States in 1958 with a sprinkler irrigation system, the first drip irrigation system was applied in Israel with the tomato plant. The nitrogen utilization efficiency ratio with fertigation is up to $90 \%$ while it is $40-45 \%$ with the other fertilizer application systems (Incrocci et al., 2017). Fertigation has major such that the fertilizer dose can be given according to the plant requirement, the distribution of the fertilizer in the root zone is equal and there is a low amount of continuous nutrients in the soil solution. The use of fertigation reduces the washing of mobile nutrients such as nitrogen by up to $70 \%$ compared to conventional fertilizer applications. The advantages and disadvantages of the fertigation are summarized in Table 3.

The basic objective in effective fertigation is to meet both plant needs and to reduce nutrient element losses to the least. In order to achieve this goal, three basic variables must be accurately predicted: (i) the need for plant nutrients; (ii) the availability of soil nutrient, and (iii) the amount of nutrient available to the plant development. The availability of soil nutrients for optimal fertigation management is critical. It is important to conduct soil analysis before sowing in the soil where dense agriculture is done and prevent excessive fertilization. There are two basic approaches to effective fertilization. In the first approach, fertigation management is done with a "prescription" approach. Before fertilization and contenting, the nutrient elements in the root zone soil and the cultural methods to be applied are taken into consideration and a fertilizing prescription is prepared. The concentration of the target nutrient is given by proportioning the amount of water consumption of the plant to the appropriate dose. In the second approach, fertigation management is done with a "corrective" approach. Plant and soil analyse are periodically conducted to prevent excess or deficiency of nutrients and fertilization and content are corrected according to these results (Giller et al., 2004). Both approaches together can be implemented by integrating for plants. Before planting, fine-tune in fertigation is made with the fertilizer dose and content determined with the "prescription" approach by determining the changes in nutrient content of the plants in the coming period conducted periodically by plant and soil analysis in this approach, (Incrocci et al., 2017).

Plant water and fertilizer needs can be determined by simulation model. Mathematical modelling in plant nutrition has been used in many different researches. For example, the root region has been used to predict nutrient uptake of whole plant parts in determining antagonism between plant nutrients (Karlberg et al., 2006; Louison et al., 2015). Many simplified models based on the concept of nutrient intake proportional to the amount of water absorbed per unit of water can be simulated with both static and dynamic approaches in plant developmental stages, climate parameters, daily developmental grades and root zone nutrient concentrations.

Depending on the cultivation system and the complexity of the simulation, different models can be simulated for different treatments, including plant nutrition. These practices are known as decision support systems (DSS), and they are favoured by considering fertilization practices on fertilizer amounts to be applied to plants and other interactions between plant nutrient and other variables (Incrocci et al., 2017).

Among different analytical approaches, the plant control approach is used to determine the status of plant nutrients and to confirm the suitability of the nutrients in terms of quantity and type of fertilizer. The approach known as "talking plant" or "plant test" is based on the principle that the control of growth conditions is related to the physiological state of the plant (Nishina, 2015). To achieve this goal, the status of nutrients in plant tissues is determined by direct and indirect measurements. The key features of the "talking plant" method are: the measurements are easy and fast, and with many measurements made, the plant is achieving results that represent the true sense of the plant. One of the most promising technologies in plant control is the rapidly evolving optical sensors. Tissue (leaf) chlorophyll fluorescence, reflection and transmission can be measured with these sensors, so plant indexes which can be related to plant stress and nutrient status can be calculated. Among the portable optical sensors, SPAD-502 is the most commonly used chlorophyll-meter. SPAD produces an index that is linearly related to the $\mathrm{N}$ concentration in leaf blade. With this index, estimates are made to determine the $\mathrm{N}$ concentration in plant tissues and these values are used in $\mathrm{N}$ fertilization (Munoz-Huerta et al., 2013), (Table 4). Plant nutrient content and stress status can be determined with the newly developed Dualex Scientific named tool which produces four different indices related to chlorophyll, flavanols, anthocyanins and nitrogen concentration derived from nitrogen balance index (NBI) (Goulas et al., 2004). The sensors that can measure the reflections in the plant tissue are divided into two main groups. Multispectral sensors, such as CropScan and FieldSpec, that measure passive solar reflectance in plant canopies and sensors that measure light reflection in plants by producing light sources such as N Sensor and 
GreenSeeker, because they are not dependent on ambient light (Munoz-Huerta et al., 2013). Multispectral imagery has been described in many studies that have used plant canopies to predict the nutrient content and to manage fertilization. Canopy reflection measurements are based on the relationship between visible and near infra-red (NIR) wave and plant canopy (Fox and Walthall, 2008). Reflection values at these specific wavelengths are used to calculate different index values, the most common of which can be used to compare normalized difference vegetation index (NDVI), indices for healthy and stressed plants, collected data (Munoz-Huerta et al., 2013).

Soil testing to control nutrient availability in the root zone is a valuable alternative to plant control. For optimal yield and quality crop production, the amount of nutrient required or the concentration of the optimal nutrient in the root zone soil volume is modulated by fertigation modalities. Soil solution sampling by lysimeter method was used in many researches and it was found effective to use in $\mathrm{N}$ management of greenhouse plants. However, the variability of the measurement results due to the very different variation of the soil nutrient solution concentration at different locations limits the commercial use of this technique (Granados et al., 2013). Recently, N and $\mathrm{P}$ determination studies based on near infrared region beam reflections (NIR) without soil sampling have been done recently (Bansod and Thakare, 2014). Here the measurement is made by spectroscopes or devices with LED lamps that emit monochromatic light at the wavelength of the absorption range of the element being investigated. In the near future it is expected that these sensors will be able to determine other different chemical elements in the soil (Incrocci et al., 2017).

Although there are many studies based on plant control to evaluate the plant nutrient status, very few applicable protocols have been developed. The high variability of nutrient concentrations in plant tissues and the necessity of having knowledge of different critical threshold levels according to culture system, climate conditions, and the difficulties of transferring them to practice limit the feasibility of this approach in a wide range of fields. For these reasons, most decision support systems (DSS) based on corrective approaches are systems in which soil inspection or soil and plant inspection methods are mixed.

\section{Automation}

Automation of irrigation and fertigation system refers to operation of the system with no or minimum manual interventions. In time based automation system, time is the basis of irrigation. Time of operation is calculated according to volume of water required and the average flow rate of water. In volume based automation system, the present amount of water can be applied in the field segments by using automatic volume controlled metering valves. In an open loop automation system, the operator makes the decision on the amount of water that will be applied and when the irrigation event will occur. This information is programmed into the controller and the water is applied according to the desired schedule. In closed loop automation system requires feedback from one or more sensors. The operator develops a general control strategy. Once the general strategy is defined, the control system takes over and makes detailed decisions of when to apply water and how much water to apply. Irrigation decisions are made and actions are carried out based on data from sensors. In this type of system, the feedback and control of the system are done continuously. Closed loop controllers require data acquisition of environmental parameters (such as soil moisture, temperature, radiation, wind-speed, etc) as well as system parameters (pressure, flow, etc.). In real time feedback system is the application if irrigation based on actual dynamic demand of the plant itself, plant root zone effectively reflecting all environmental factors acting upon the plant. Operating within controlled parameters, the plant itself determines the degree of irrigation required. A computer-based control system consists of a combination of hardware and software that acts as a supervisor with the purpose of managing irrigation and other related practices such as fertigation and maintenance. In fully automated systems the human factor is eliminated and replaced by a computer specifically programmed to react appropriately to any changes in the parameters monitored by sensors. The automatic functions are activated by feedback from field units and corrections in the flow parameters by control of devices in the irrigation system until the desired performance level is attained (Rajakumar et al., 2008).

Table 3 Advantages and disadvantages of fertigation*

\begin{tabular}{|c|c|}
\hline Advantages & Disadvantages \\
\hline $\begin{array}{l}\text { - As the nutrients are applied directly to the root zone, they can } \\
\text { be easily taken by plants } \\
\text { - } \quad \text { More flexibility in the supply of plant nutrients and } \\
\text { simultaneous uptake of plant nutrients } \\
\text { - } \quad \text { Savings in labor costs through automation in fertilizer } \\
\text { - Increase with yield and quality } \\
\text { - } \quad \text { Decrease in environmental pollution, especially by } \\
\text { preventing nitrogen leaching } \\
\text { - } \quad \text { Able to use special fertilizers to prevent minerals deficiencies } \\
\text { Improvement in medium-high saline irrigation management } \\
\text { and prevention of low yield }\end{array}$ & $\begin{array}{l}\text { - The initial investment costs are high in the } \\
\text { installation of the fertigation system } \\
\text { - The risk of washing of the nutrients during the } \\
\text { rainy season } \\
\text { - Especially in clayey soil, roots to remain } \\
\text { airless due to frequent irrigation of plant } \\
\text { - Experienced staff needs } \\
\text { - Risks of clogging of drippers with } \\
\text { precipitation of insoluble salts }\end{array}$ \\
\hline
\end{tabular}

*Incrocci et al. (2017) 
Table 4 Advantages and disadvantages with $\mathrm{N}$ identification techniques in plant

\begin{tabular}{|c|c|c|c|c|c|}
\hline \multicolumn{4}{|c|}{ Technique } & Advantages & Disadvantages \\
\hline \multirow{2}{*}{\multicolumn{3}{|c|}{ Tissue Analysis }} & Kjeldahl & $\begin{array}{l}\text { Applied reference method for } \\
\text { determining total } \mathrm{N} \text { content }\end{array}$ & $\begin{array}{l}\text { Destructive, Time consuming, } \\
\text { Toxic reagent use, Sampling } \\
\text { preprocessing }\end{array}$ \\
\hline & & & Dumas & $\begin{array}{l}\text { Does not contain nitrate and } \\
\text { nitrite reduction }\end{array}$ & $\begin{array}{l}\text { Destructive, Time consuming, } \\
\text { Nitrogen loss due to incomplete } \\
\text { combustion, Sampling } \\
\text { preliminary }\end{array}$ \\
\hline \multirow{6}{*}{$\mathrm{OM}$} & \multirow[b]{2}{*}{ On leaf } & Permeability & SPAD & $\begin{array}{l}\mathrm{N} \text { and leaf are not destructive } \\
\text { due to the high correlation } \\
\text { between chlorophyll content, } \\
\text { and is portable }\end{array}$ & $\begin{array}{l}\text { Inaccurate measurement due to } \\
\text { chlorophyll saturation in overfed } \\
\text { plants, Low sensitivity in early } \mathrm{N} \\
\text { stress detection }\end{array}$ \\
\hline & & Fluorescence & Dualex & $\begin{array}{l}\text { It can remove false signals } \\
\text { coming from bare earth, it can } \\
\text { distinguish between full } \\
\text { sunlight shadows and different } \\
\mathrm{N} \text { dose applications, it is } \\
\text { portable, Multiplex can detect } \\
\mathrm{N} \text { deficiency among other } \\
\text { stresses such as water and } \\
\text { disease }\end{array}$ & $\begin{array}{l}\text { It will only be able to be applied } \\
\text { in large areas due to technology } \\
\text { development in the near future }\end{array}$ \\
\hline & \multirow{4}{*}{ On flora } & \multirow{3}{*}{ Of the earth } & $\begin{array}{l}\text { Passive } \\
\text { sensor; } \\
\text { FieldSpec, } \\
\text { CropScan, LI } \\
1800\end{array}$ & $\begin{array}{l}\mathrm{N} \text { can be detected in larger field } \\
\text { compared to leaf-based } \\
\text { measurements }\end{array}$ & $\begin{array}{l}\text { Calibration is required, it depends } \\
\text { on sunlight }\end{array}$ \\
\hline & & & Digital camera & No complicated device needed & $\begin{array}{l}\text { It is still dependent on daylight. } \\
\text { Although fuzzy logic models are } \\
\text { used to reduce the effects of } \\
\text { sunlight with recent studies, plant } \\
\mathrm{N} \text { content analysis is still required }\end{array}$ \\
\hline & & & $\begin{array}{l}\text { Active sensor; } \\
\text { GreenSeeker } \\
\text { Yara } \\
\text { N-Sensor } \\
\text { CropCircle }\end{array}$ & $\begin{array}{l}\text { There is no dependence on the } \\
\text { sunlight on its own light source. } \\
\text { The Yara can measure more } \\
\text { biomass for each unit soil area, } \\
\text { GreenSeeker N can determine } \\
\mathrm{N} \text { variations in vegetation cover } \\
\text { even near the saturation }\end{array}$ & $\begin{array}{l}\text { They are expensive equipment, } \\
\text { Saturation increases with biomass } \\
\text { increase, GreenSeeker measures } \\
\text { only two wavelengths, Yara N } \\
\text { can not measure near saturation, } \\
\text { GreenSeeker reaches saturation } \\
\text { before CropScan in plant } \\
\text { development phase }\end{array}$ \\
\hline & & Satellite & QuickBird & It can measure in whole field & $\begin{array}{l}\text { Expensive imaging is affected by } \\
\text { Atmospheric conditions, Re- } \\
\text { imaging time from the same spot } \\
\text { is longer, image resolution is low }\end{array}$ \\
\hline \multirow{3}{*}{\multicolumn{3}{|c|}{$\begin{array}{l}\text { Plant Extraction and Electrical } \\
\text { Metering }\end{array}$}} & $\begin{array}{l}\text { Nitrate Test } \\
\text { Strips }\end{array}$ & $\begin{array}{l}\mathrm{N} \text { can be estimated due to high } \\
\text { correlation between plant } \mathrm{N} \\
\text { status and plant sap water } \\
\text { nitrate concentration, Cheap } \\
\text { and Portable, Fast measurement }\end{array}$ & $\begin{array}{l}\text { Exposure to light causes nitrate } \\
\text { changes in the measurement, } \\
\text { Plant sap dilutions are necessary, } \\
\text { Destructive, } \mathrm{N} \text { is not measured } \\
\text { other than nitrate, so total } \mathrm{N} \\
\text { determination is not possible }\end{array}$ \\
\hline & & & Nitrate ISE & $\begin{array}{l}\mathrm{N} \text { estimation can be done } \\
\text { because of the high correlation } \\
\text { between plant sap nutrition } \\
\text { content and plant } \mathrm{N} \text { status, } \\
\text { Nitrate has a wider working } \\
\text { range than test strips }\end{array}$ & $\begin{array}{l}\text { It is susceptible to other ions such } \\
\text { as chlorine, bicarbonate and } \\
\text { nitrite, It is destructive, } \\
\text { Calibration and plant juice } \\
\text { dilutions are necessary. It is not } \\
\text { possible to determine the total } \mathrm{N} \\
\text { accurately because other } \mathrm{N} \text { forms } \\
\text { other than nitrate are not } \\
\text { measured }\end{array}$ \\
\hline & & & $\begin{array}{l}\text { Electrical } \\
\text { Impedance } \\
\text { Spectroscopy }\end{array}$ & $\begin{array}{l}\text { Direct measurement of } \\
\text { electrical properties of plant } \\
\text { tissue }\end{array}$ & $\begin{array}{l}\text { Destructor, affecting electrode } \\
\text { polarization, there are a few } \\
\text { related works }\end{array}$ \\
\hline
\end{tabular}


An automated fertigation system can be integrated with the facility's environmental control system where it can be monitored and managed from a centralized user interface along with all the other controlled processes within the grow operation. Fertigation systems vary with each application and should be capable of adapting to the design and operation of the overall facility. This may include controls and monitoring for: tank levels, $\mathrm{EC}, \mathrm{pH}$, acid/base dosing equipment, water temperature, soil moisture levels, leaching rates (overdrawn), nutrient dosing equipment, pump controls, irrigation zone valves, line purging, recirculation management, water treatment equipment (filters, pasteurizers, ozone, UV, etc.).

\section{Discussion}

The advantages associated with precision irrigation and fertigation include increased crop yields, improved crop quality, improved water and nutrition use efficiency/savings, reduction of energy costs and reduction of adverse environmental impacts (Shah and Das, 2012). Pierce (2010) viewed precision irrigation as a tool for improving sustainability in irrigated agriculture in terms of improved irrigation water use efficiency and improved environmental quality of irrigated fields. Each system has its own advantages and disadvantages. The advantages and disadvantages of each of these approaches are summarized in Tables 1, 2, 3 and 4.

\section{Conclusion and Suggestions}

Intelligent irrigation and fertilization practices applied with micro irrigation systems are one of the most effective strategies to increase nutrient utilization efficiency in agricultural production. Application of nutrients and irrigation water at low dose and high frequency improves the use of water and nutrient intake. At the same time, water and plant nutrients prevent their losses. These aspects positively affect the economic and environmental sustainability of agricultural activities.

Monitoring and control of real-time soil, plant and weather conditions are necessary for intelligent irrigation and fertilization to achieve success. There are many water and fertilizer management techniques. Choosing the most appropriate technique is not easy because all of them have their advantages and disadvantages. Factors such as plant type, irrigation water quality and accessibility, soil and structure, infiltration rate, organic matter, salinity, slope, climate data, irrigation and plant production systems, land size, ease of implementation, economic and technical infrastructure are the necessary considerations in selecting the technique. When optimal water and fertilizer management techniques are applied, high quality and high yield are achieved in agricultural production, so producers get high income.

\section{References}

Adeyemi, O, Grove, I, Peets, S, Norton, T. 2017. Advanced monitoring and management systems for improving sustainability in precision irrigation. Sustainability, 9: 1-29.

Aras İ. 2006. Damla sulama. J Field Crops CRI., 15: 49-60.

Bansod SJ, Thakare SS. 2014. Near Infrared spectroscopy based a portable soil nitrogen detector design. Int. J. Comput. Sci. Inf. Technol, 5: 3953-3956.
Bin Mohd Juaser.2014. Smart fertigation system for plants. A thesis submitted in fulfilment of the requirements for the award of the degree of Bachelor of Engineering Faculty of Electrical Engineering Universiti Teknologi Malaysia.

Blanco M. 2011. Supply of and access to key nutrients NPK for fertilizers for feeding the world in 2050. Agronomies Etsiaupm. We Engineer Life Food and Environment.

Blonquist JM, Norman JM, Bugbee B. 2009. Automated measurement of canopy stomatal conductance based on infrared temperature. Agric. For. Meteorol, 149: 2183-2197.

Bogena HR, Huisman JA, Oberdörster C, Vereecken H. 2004. Evaluation of a low-cost soil water content sensor for wireless network applications. J. Hydrol, 344: 32-42.

Brentrup F, Palliere B. 2011.Nitrogen use efficiency as an agroenvironmental indicator. Yara International Research Centre.

Çetin Ö. 2015. Fertigasyon: Sulama ile birlikte gübreleme. Dicle Ü. Ziraat Fak. Tarımsal Yapılar ve Sulama Bölümü, Diyarbakır.

Ekici E, Alişarlı M, Sancak YC. 2008. Peynir çeşitlerinde nitrit ve nitrozaminler, YYÜ Veteriner Fakültesi Dergisi, 2: 71-72.

Erdem Y, Arin L, Erdem T, Polat S, Deveci M, Okursoy H, Gültas HT. 2010. Crop water stress index for assessing irrigation scheduling of drip irrigated broccoli (Brassica oleracea L. var. italica). Agric Water Manag., 98: 148-156.

FAO. 2016. Current world fertilizer trends and outlook to 2018. Rome, Italy, pp: 66.

Fox RH, Walthall CL. 2008. Crop monitoring technologies to assess nitrogen status. In Nitrogen in Agricultural Systems; American Society of Agronomy: Madison, WI, USA, pp: 647-674.

French R, Bowling R, Abbott A, Stewart M. 2014. High Yield Irrigated Corn: Implementing Research and Adapting for Profitable Production. Great Plains Soil Fertility Conference, Denver, CO. 15: 78-83.

Geesing D, Bachmaier M, Schmidhalter U. 2004. Field calibration of a capacitance soil water probe in heterogeneous fields. Aust. J. Soil Res., 42: 289-299.

Giller KE, Chalk P, Dobermann A, Hammond L, Heffer P, Ladha JK, Nyamudeza P, Maene L, Ssali H, Freney J. 2004. Emerging technologies to increase the efficiency of use of fertilizer nitrogen. In Agriculture and the Nitrogen Cycle; Mosier A, Syers JK, Freney JR, Eds.; Island Press: New York, NY, USA, p: 344.

Goulas Y, Cerovic ZG, Cartelat A, Moya I. 2004. Dualex: A new instrument for field measurements of epidermal ultraviolet absorbance by chlorophyll fluorescence. Appl. Opt., 43: 4488-4496.

Granados MR, Thompson RB, Fernandez MD, Martinez-Gaitan C, Gallardo M. 2013. Prescriptive-corrective nitrogen and irrigation management of fertigated and drip-irrigated vegetable crops using modelling and monitoring approaches. Agric. Water Manag., 119: 121-134.

Gupta ML, Khosla R. 2014. Precision nitrogen management and global nitrogen use efficiency. https://www.ispag.org/.../abstract_1013.docx (Accessed April, 2017).

Hunsaker DJ, Pinter PJ, Barnes EM, Kimball BA. 2003. Estimating cotton evapotranspiration crop coefficients with a multispectral vegetation index. Irrig. Sci., 22: 95-104.

Incrocci L, Massa D, Pardossi A. 2017. New trends in the fertigation management of irrigated vegetable crops. Horticulture, 3 (37): 1-20.

Jones JW, Hoogenboom G, Porter CH, Boote KJ, Batchelor WD, Hunt LA, Wilkens PW, Singh U, Gallardo M, Thompson RB, Gimenez C, Padilla FM, Stöckle CO. 2014. Prototype decision support system based on the VegSyst simulation model to calculate crop $\mathrm{N}$ and water requirements for tomato under plastic cover. Irrig. Sci., 32: 237-253. 
Karaşahin M. 2014a. Bitkisel üretimde azot alım etkinliği ve reaktif azotun çevre üzerine olumsuz etkileri. APJES., II-III: 15-21.

Karaşahin M. 2014b. Effects of different irrigation methods and plant density on silage yield and yield components of PR 31Y43 hybrid corn cultivar. Turk J Agric For., 38: 159-168.

Karlberg L, Ben-Gal A, Jansson PE, Shani U. 2006. Modelling transpiration and growth in salinity-stressed tomato under different climatic conditions. Ecol Model., 190: 15-40.

Louison L, Omrane A, Ozier-Lafontaine H, Picart D. 2015. Modeling plant nutrient uptake: Mathematical analysis and optimal control. Lect Notes Pure Appl., 4: 193-203.

Lozoya C, Mendoza C, Mejia L, Quintana J, Mendoza G, Bustillos M, Arras O, Solis L. 2014. Model predictive control for closed-loop irrigation. IFAC Proc. Vol. (IFACPapers Online), 19: 4429-4434.

Liu H, Yang H, Zheng J, Jia D, Wang J, Li, Y. Huang, G. 2012. Irrigation scheduling strategies based onsoil matric potential on yield and fruit quality of mulched-drip irrigated chili pepper in Northwest China. Agric. Water Manag., 115: 232241.

McCarthy AC, Hancock NH, Raine SR. 2010. VARI wise: A general-purpose adaptive control simulation framework for spatially and temporally varied irrigation at sub-field scale. Comput. Electron. Agric., 70: 117-128.

Meron M, Tsipris J, Orlov V, Alchanatis V, Cohen Y. 2010. Crop water stress mapping for site-specific irrigation by thermal imagery and artificial reference surfaces. Precis Agric., 11: 148-162.

Mulla DJ. 2013. Twenty five years of remote sensing in precision agriculture: Key advances and remaining knowledge gaps. Biosyst. Eng., 114: 358-371.

Munoz-Carpena R, Shukla S, Morgan K. 2004. Field devices for monitoring soil water content. Education, and Extension Service, U.S. Department of Agriculture, 1-22.

Munoz-Huerta RF, Guevara-Gonzalez RG, Contreras-Medina LM, Torres-Pacheco I, Prado-Olivarez J, OcampoVelazquez RV. 2013. A review of methods for sensing the nitrogen status in plants: Advantages, disadvantages and recent advances. Sensors, 13: 10823-10843.

Nishina H. 2015. Development of speaking plant approach technique for intelligent greenhouse. Agric Sci Proc., 3: 913.

Pereira LS, Allen RG, Smith M, Raes D. 2014. Crop evapotranspiration estimation with FAO56: Past and future. Agric Water Manag., 147: 4-20.
Phillips AJ, Newlands NK, Liang SHL, Ellert BH. 2014. Integrated sensing of soil moisture at the field-scale: Measuring, modelling and sharing for improved agricultural decision support. Comput Electron Agric., 107: 73-88.

Pierce FJ. 2010. Precision Irrigation. Land bauforsch SH., 340: 45-56.

Prakashgoud P, Desai BL. 2013. Intelligent Irrigation Control System by Employing Wireless Sensor Networks Patil. Int J Comput Appl., 79: 33-40.

Rajakumar D, Ramah K, Rathika S, Thiyagarajan G. 2008. Automation in micro-irrigation. Science Tech Entrepreneur., 1-8.

Rani PMN, Rajesh T, Saravanan R. 2011. Expert Systems in Agriculture: A Review. Int J Sci Technol Eng., 3: 59-71.

Rowlandson TL, Berg AA, Bullock PR, Ojo ER, McNairn H, Wiseman G., Cosh MH. 2013. Evaluation of several calibration procedures for a portable soil moisture sensor. J Hydrol., 498: 335-344.

Shah NG, Das I. 2012. Precision Irrigation: Sensor Network Based Irrigation. In Problems, Perspectives and Challenges of Agricultural Water Management; InTech: Rijeka, Croatia., 217-232.

Shaughnessy SAO, Evett SR, Colaizzi PD. 2014. Infrared Thermometry as a Tool for Site-Specific Irrigation Scheduling. In Proceedings of the 26th Annual Central Plains Irrigation Conference, Burlington, CO, USA,25-26 February 2014; pp: 136-145.

Singh SK, Dutta S, Dharaiya N. 2013. Estimation of Crop Evapotranspiration of Cotton using Remote Sensing Technique. Int . Environ Eng Manag., 4: 523-528.

Smith RJ, Baillie JN, Futures I. 2009. Defining precision irrigation: A new approach to irrigation management. In Proceedings of the Irrigation and Drainage Conference 2009, Swan Hill, Australia, October 2009; pp. 18-21.

Steele DD, Stegman EC, Gregor BL. 1994. Field Comparison of Irrigation Scheduling Methods for Corn. Trans. Asae, 37: 1197-1203.

Vellidis G, Tucker M, Perry C, Kvien C, Bednarz C. 2008. A real-time wireless smart sensor array for scheduling irrigation. Comput Electron Agric., 61: 44-50.

Zarco-Tejada PJ. 2014. Precision Agriculture: An Opportunity For Eu Farmers Potential Support With The Cap 20142020.Joint Research Centre (JRC) of the European Commission, Monitoring Agriculture Resources.

Zotarelli L, Scholberg JM, Dukes MD, Muñoz-Carpena R. 2008. Fertilizer Residence Time Affects Nitrogen Uptake Efficiency and Growth of Sweet Cor, J Environ Qual., 37: 1271-1278. 